\title{
Histopathology of Interrelations between Fusarium oxysporum f. sp. dioscoreae and two nematode species on yam ${ }^{1,2}$
}

\author{
Ana E. Montalvo and Pedro L. Meléndez ${ }^{3}$
}

\begin{abstract}
Experiments were conducted in the greenhouse to elucidate the histopathological effects of a possible interrelationship between the nematodes Meloidogyne incognita and Pratylenchus colfeae and the fungus Fusarium oxysporum t. sp. dioscoreae on yam (Dioscorea rolundata cv Habanero). Separate and combined inoculations were made with the fungus and the nematodes. Longitudinal and transverse sections of root tissues collected at 14, 42 and 72 days after inoculation showed that colonization by the fungus occurred indiscriminately, either inter- or intracellularly. Colonization in the stem was restricted to the vascular system, where abundant proliferation of hyphae was observed, mainly in the nodal tissues. Apparently, the root-knol nemalode ( $M$. incognita), as well as the fungus, colonized different sectors of the tissues invaded. However, abundant and vigorous hyphae were present in sections of tissues modified by $M$. incognita. It may be concluded from these studies that a positive Meloidogyne-Fusarium interaction occurs in yam. The lesion nematode ( $P$. coffeae) was sometimes observed together with the fungus within the same tissues. However, this association did not appear to considerably accelerate the severity and/or the incidence of wilt caused by Fusarium.
\end{abstract}

\section{INTRODUCTION}

Yam (Dioscorea spp.) is an important and preferred food in the tropics. In the Caribbean countries it is one of the most extensively cultivated starchy root crops. In Puerto Rico yams are generally grown by small farmers in the highlands. According to Luis F. Martinez from the statistics section of the Department of Agriculture of Puerto Rico (personal communication) yam production in 1983-84 was 283,000 cwt with a gross farm income of $\$ 6,245,000$. However, continued profitable production and potential expansion of this important crop are threatened by diseases caused by plant parasitic nematodes and fungi.

The root-knot nematode, Meloidogyne incognita (Kofoid and White) Chitwood, and the lesion nematode, Pratylenchus coffeae (Zimmerman) Filipj, and Schuur. Stekh., can reduce yieid and marketability of yams $(2,3)$. This is mainly due to the lesions caused through parasitism which facilitate invasion by fungi and other microorganisms (19). In Puerto Rico, these nematodes (2) and Fusarium oxysporum f, sp. dioscoreae

' Manuscript submitted to Editorial Board April 11, 1985.

${ }^{2}$ Part of a thesis submitted to the Graduate School, University of Puerto Rico, Mayagüez Campus, in partial fulfillment of the requirements for the Master of Science degree at the Faculty of Agriculture-1983.

${ }^{3}$ Research Assistant, Department of Crop Prolection; and Phytopathologist and former Assnciate Dean, respectively. Faculty of Agriculture, University of Puerto Rico, College of Agricultural Sciences, Mayagüez Campus. 
Wellman, which causes the wilt disease (19), are important pests of yams.

The pathogenicity of the fungus on $D$. rotundata was established by López and Meléndez (13).

Although phytoparasitic nematodes affect their hosts directly, their major importance to plant diseases are the result of a complex etiology that involves other microorganisms, including fungi $(17,19)$. The occurrence of disease interactions is more important than was earlier thought. Plants, normally resistant to certain fungi, become susceptible to these pathogens when infected with nematodes. Moreover, the incidence and severity of fungus diseases are increased when compared to those of nematode-free plants $(16,17,18,19)$.

The host-parasite interaction of several nematode genera and Fusarium has been studied histologically in other crops $(4,11,16)$. In Puerto Rico, similar studies have not been performed on yam. This paper presents detailed observations and descriptions of the effects of these pathogens when acting alone or in combination in root and stem tissues of yam.

\section{MATERIALS AND METHODS}

Six-month-old Guinea yam ( $D$. rotundata Poir) plants established from stem cuttings in sterile soil were used for the tests. Plantlets were grown to transplant size in 4-liter metal containers and carefully removed and transplanted to wooden observation boxes $(52 \times 42 \times 20 \mathrm{~cm})$ containing $2,500 \mathrm{~cm}^{3}$ of a methyl bromide-treated 1:1:1 alluvial sandy loam, organic soil and sand mixture. Three small yam plants were planted in each box. Boxes were equipped with glass sides to permit observation of disease development. The glass was covered with a sliding wood panel except when observations were being made (fig. 1 ). At the time of transplanting, three open-end glass inoculation tubes $(15 \times 1 \mathrm{~cm})$ were placed equidistantly around each yam plant, with one end in contact with the roots. All inoculations were made through the tubes (fig. 2). Codes assigned to the various treatments are summarized as follows:

\section{Code Inoculation treatment}

\begin{tabular}{|c|c|}
\hline M & M. incognita alone \\
\hline $\mathbf{P}$ & $P$. coffeae alone \\
\hline $\mathbf{F}$ & F. oxysporum f. sp. dioscoreae alone \\
\hline $\mathrm{M}+\mathrm{F}-\mathrm{S}$ & $\begin{array}{l}\text { M. incognita and } F \text {. oxysporum f. sp. dioscoreae simulta- } \\
\text { neously }\end{array}$ \\
\hline $\mathrm{P}+\mathrm{F}-\mathrm{S}$ & $\begin{array}{l}P \text {. coffeae and } F \text {. oxysporum f. sp. dioscoreae simultane- } \\
\text { ously }\end{array}$ \\
\hline $\mathrm{M}+\mathrm{F}-4$ & F. oxysporum f. sp. dioscoreae 4 weeks after $M$. incognita \\
\hline $\mathrm{P}+\mathrm{F}-4$ & $F$. oxysporum f. sp. dioscoreae 4 weeks after $P$. coffeae \\
\hline Check & Noninoculated plants \\
\hline
\end{tabular}


J. Agric. Univ. P.R. vol. 70, No. 4, OCTOBER, 1986

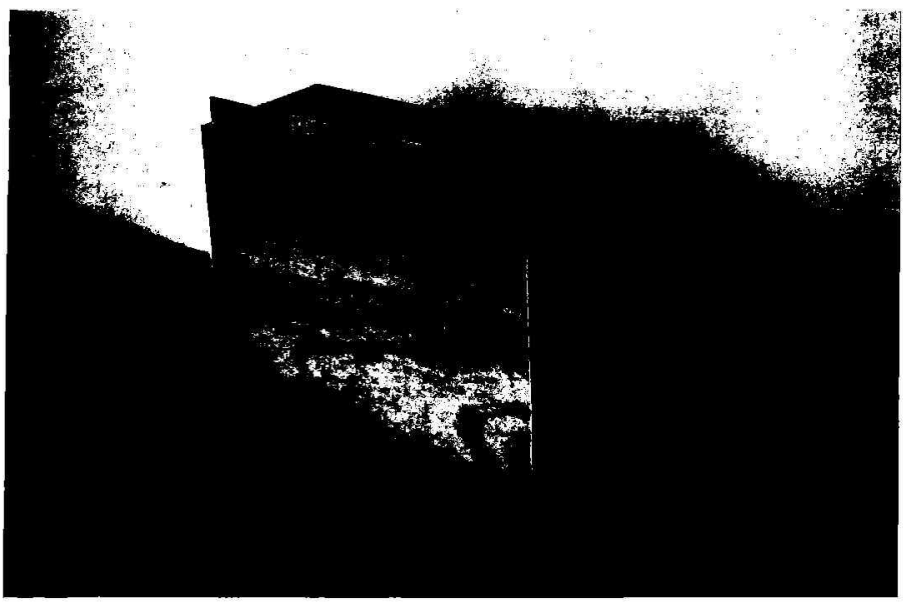

Fic. 1.-Wooden observation box equipped with a glass side covered with a sliding wood panel.

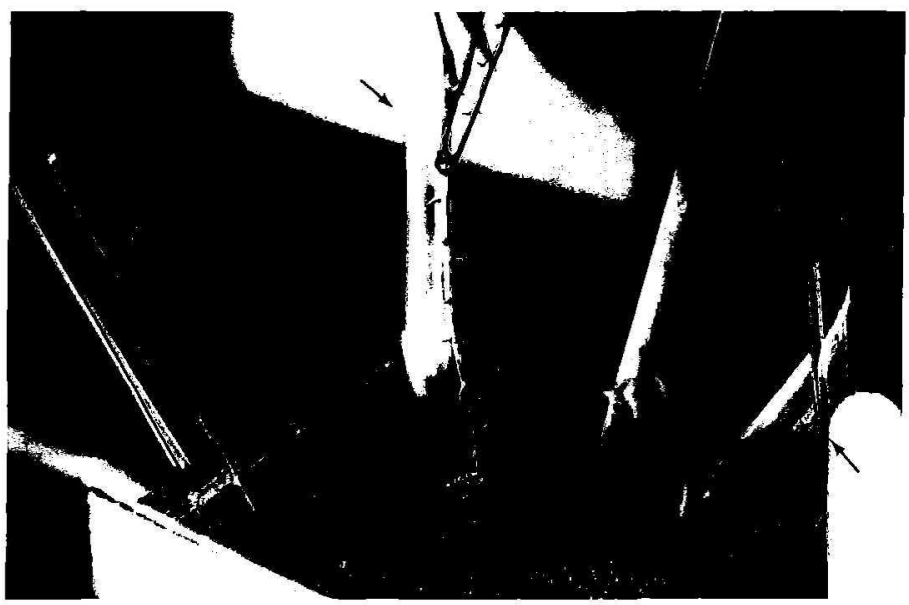

FIG. 2--Inoculation tubes placed equidistantly around yam plants. 
Treatments were replicated three times, and three groups of nine plants each received separately $1,000 P$. coffeae $(\mathrm{P})$ specimens; 2,000 eggs and second stage juveniles of $M$. incognita $(M)$ and $60 \mathrm{ml}$ of a $F$. oxysporum $\mathrm{f}$. sp. dioscoreae (F) suspension/plant.

All microorganisms intended for inoculations were separately maintained on yam plants in the greenhouse. The initial $M$. incognita inoculum was obtained from infected yam roots from rural section Arenales in Aguadilla, Puerto Rico. The original $P$. coffeae inoculum was isolated from infected yam tubers obtained from a commercial planting from Jagüey in Aguada, Puerto Rico. Eggs and second stage juveniles of $M$. incognita used for inoculations were extracted from infected yam roots according to the method described by Hussey and Barker (9). Inoculum of $P$. coffeae was extracted from infected yam tissues with Baermann funnels. Nematode inoculum was poured into each of the three glass inoculation tubes previously placed around the plant roots. Each tube was then rinsed with distilled water to insure that the respective inoculum reached the roots at the bottom of the tube. $F$. oxysporum was isolated from infected yam stems in the Atalaya section in Aguada, Puerto Rico. Techniques used in fungus culture, inoculum preparation and inoculation were described by Meléndez and Powell (15).

Plants were harvested 14, 42 and 72 days after inoculation, and samples of roots and stem were collected for histological examination. Following the usual procedures (12), small portions of fresh roots and stems from each treatment were fixed in FAA, dehydrated with a tertiary butyl alcohol series, embedded in 56 to $57^{\circ} \mathrm{C}$ paraplast and sectioned longitudinally and transversely on a rotatory microtome at $12 \mu \mathrm{m}$ thickness. Sections were adhered to glass slides with Haup's adhesive and 3\% formalin, stained in safranin and fast green for $10 \mathrm{~min}$ and $5 \mathrm{~s}$, respectively, and mounted in Fisher's Permount before microscopic examination.

At the time of collecting the samples, the aerial portion of each plant was examined to detect the presence of Fusarium wilt symptoms such as wilting and vascular browning.

\section{RESULTS AND DISCUSSION}

\section{FOURTEEN DAYS AFTER INOCULATION}

At this period, plants, irrespective of the treatments, did not exhibit wilt symptoms nor vascular discoloration. However, histological studies of root tissues revealed the presence of fungal hyphae in the epidermal cells and in the cortex parenchyma of all plants inoculated with $F$. oxysporum (fig. 3A).

No histological evidence of fungal colonization was observed in vessel elements either in roots or stem sections during this period in the 


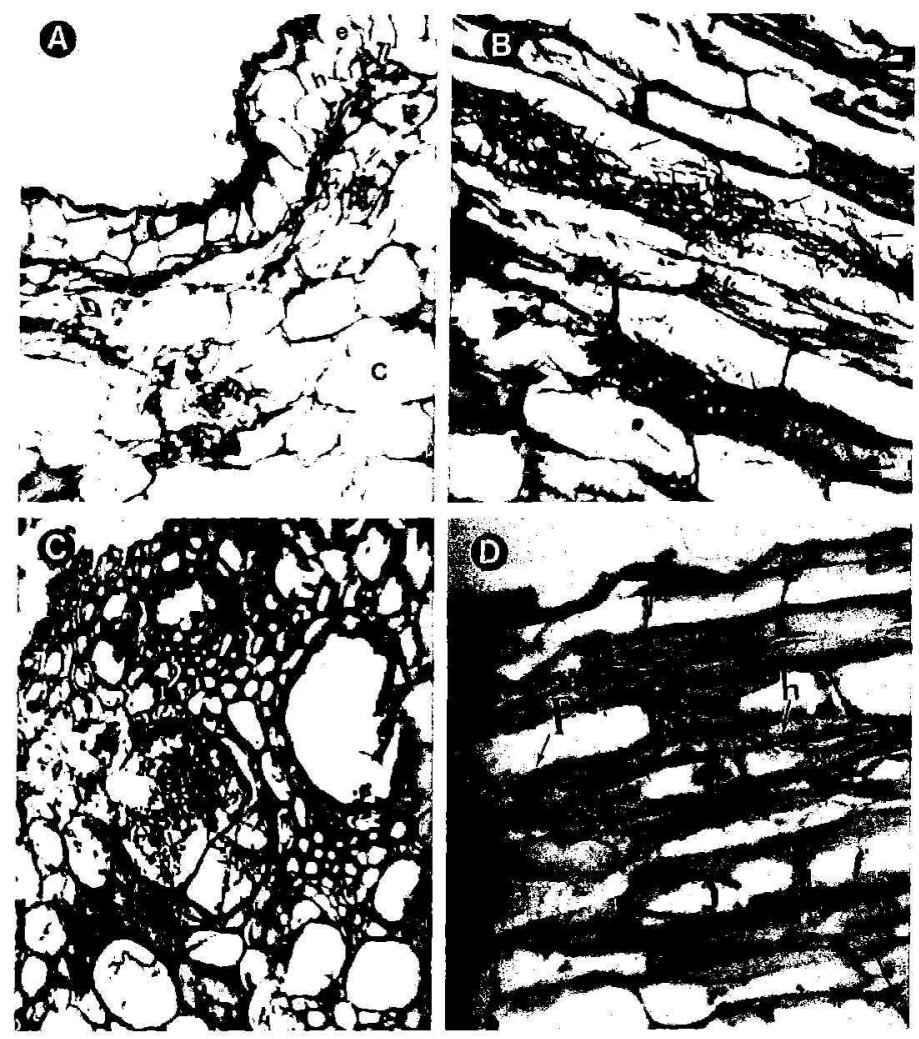

FIG, 3.-Yam root and stem sections from plants 14 and 72 days after inoculation. A) Cross section of a root at 14 days with $F$. oxysporum showing hyphae $(h)$ invading epidermal (e) and cortical (c) tissues $(300 \times)$. B) Longitudinal section of a root from plants inoculated with $M$. incognita 4 weeks before inoculation with the fungus at 42 days $(300 \times)$. Note the abundance of hyphae in the cortex. C) Cross section of stem from plants inoculated with $M$. incognita 4 weeks before fungus inoculation at 42 days showing extensive colonization of the vessel elements $(300 \times)$. D) Longitudinal section of a root at 42 days from plants inoculated with $P$. coffeae $(\mathrm{P}) 4$ weeks before inoculation with the fungus $(300 \times)$.

treatments to which the fungus was added. This apparent absence of Fusarium in the vascular tissues may be due to sampling error, or to the fact that fungus colonization of such tissues was so limited as to remain undetected during the first 2 weeks after inoculation. 
Evidence of root-knot nematodes could not be observed in root tissues during this period, apparently, because of the short interval that elapsed for eggs to hatch and for infective juveniles to penetrate root tissues.

Histological observations of root sections showed the presence of $P$. coffeae in the first two or three layers of cortical cells below the epidermis. Occasionally, some necrosis was observed in these cells. In some sections, the epidermis appeared disrupted and necrotic, probably, among other causes, because of damage inflicted by the nematodes at their points of entry. There was no evidence of fungus and nematode invading the same cells within the tissues at any given observation for this period.

\section{FORTY-TWO DAYS AFTER INOCULATION}

Wilt symptoms were detected in treatments $\mathrm{M}+\mathrm{F}-\mathrm{S}, \mathrm{P}+\mathrm{F}-\mathrm{S}, \mathrm{M}+\mathrm{F}-4$ and $\mathrm{P}+\mathrm{F}-4$. Symptoms were more severe in plants from treatment $\mathrm{M}+\mathrm{F}-4$. Apparently, these tissues from these plants were physiologically modified and became more susceptible to fungus invasion than those of plants from other treatments. Vascular discoloration was detected in the stem, mainly in the nodal area of all plants inoculated with $F$. oxysporum, irrespective of treatments, but the symptoms were more severe on plants from treatment $M+F-4$. Fungal growth was detected in the cortical and in the xylem vessel tissues in sections prepared from roots in all treatments, but much more evident in cortical cells of plants from treatment $\mathrm{M}+\mathrm{F}-4$ (fig. 3B).

Histological studies of stem tissues revealed that colonization by the fungus was restricted to the vascular system in all plants inoculated with $F$. oxysporum, but once more the invasion was much more extensive in plants to which the root-knot nematode was added 4 weeks before the fungus (fig. 3C).

There was evidence of infective larvae of $M$. incognita in the cortical tissues of root sections. It is postulated that movement through the cortex is intercellular because no physical derangement of these tissues attributable to the passage of the larvae was observed. Christie (5), made similar observations on root tips of tomato seedlings.

In many cases, numerous mature females were observed within the tissue in apparent feeding position and the nematode's head was surrounded by giant cells. These cells became multinucleated, had a dense and granular cytoplasm and were thick-walled. Also a great number of very small disorganized cells bordered giant cells. In sections where the heads of the nematodes were clearly visible, these were always observed to occupy the intercellular spaces between the giant cells.

$P$. coffeae was observed to lie deeper into the cortex and oriented longitudinally and adjacent to the vascular elements. When the nematode 
appeared associated with $F$. oxysporum in root tissues, the fungus colonized the cortical region in plants within treatments $\mathrm{P}+\mathrm{F}-\mathrm{S}$ and $\mathrm{P}+\mathrm{F}-4$ (fig. 3D).

\section{SEVENTY-TWO DAYS AFTER INOCULATION}

Fusarium wilt disease was aggravated in plants to which the root-knot nematode was added 4 weeks before the fungus. This was evidenced by the incidence of wilt in which all plants under this treatment were dead at the time the data was taken. However, the same was not true for plants to which either organism was added alone, since none of the plants were dead, regardless of the wilt symptoms. These observations again emphasize the fact that root-knot nematodes increase disease severity and incidence when added for a considerable period of time before inoculation with the fungus. This agrees with findings in other crops (14, $15,16,17,19$ ).

Vascular discoloration was observed mainly in the nodal area in plants from treatment $\mathrm{M}+\mathrm{F}-4$. The same was true for plants collected 42 days after inoculation.

Histological examination of root tissues revealed that colonization by the fungus occurred indiscriminately, either inter- or intracellularly. This caused a high degree of necrosis in all treatments where the fungus was present. Abundant fungal growth was detected in the xylem tissues, especially in plants inoculated with $M$. incognita 4 weeks before the fungus (fig. $4 \mathrm{~A}$ ). Likewise, in tissues examined 42 days after inoculation, stem colonization was restricted to the vascular system, where abundant proliferation of hyphae was observed, mainly in nodal tissues. Fungal hyphae also appeared highly vigorous in that area, mostly in plants from treatment $\mathrm{M}+\mathrm{F}-4$ (fig. 4C). This coincided with a high degree of discoloration observed in these tissues. It seems probable that the frequent plugging of the nodal area by fungal hyphae could be one of the causes of wilting. Dimond (6) reported that wilt disease could result from various factors, some of which are plugging of the vascular elements by the pathogen or by toxins and other waste products produced by the pathogen and/or the host plant.

Histological sections prepared from roots showed that $M$. incognita infection caused damage in epidermal, cortical and vascular tissues as the result of giant and hyperplastic cell formation. Similar studies, reported by Jenkins and Bird (11) in Dioscorea sp. infected with $M$. incognita, revealed cortical destruction and disruption of xylem elements.

Histological studies of root tissues of the $M$. incognita- $F$. oxysporum combination revealed that each species colonized different sectors in these tissues, since the fungus was detected in areas other than those 

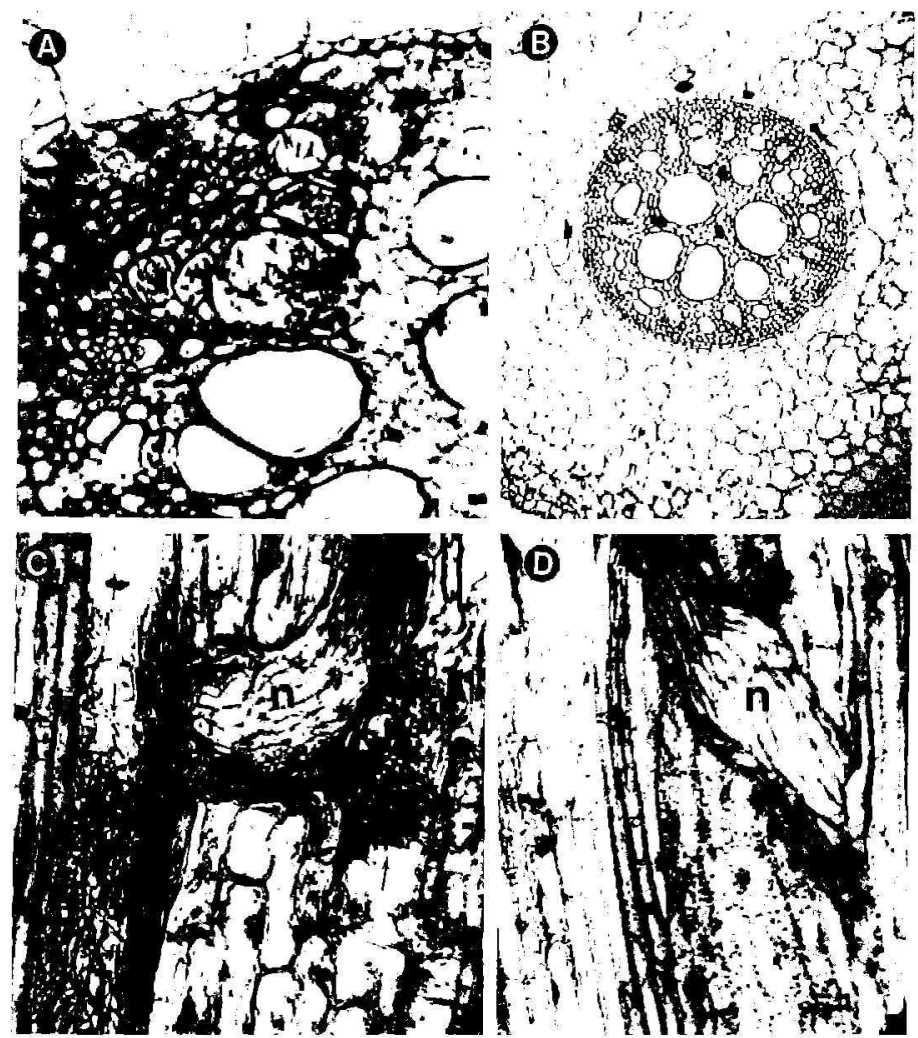

Fig. 4.-Yam root and stem sections (rom plants 72 days after inoculation. A) Cross section of a root from plants inoculated with $M$. incognita 4 weeks before inoculation with $F$. oxysporum showing vigorous hyphae within the xylem vessels $(300 \times)$. B) Cross section of a non-inoculated root $(100 \mathrm{x})$. C) Longitudinal section of the stem from plants inoculated with $M$. incognita 4 weeks before fungus inoculation $(300 \times)$. Note the abundant proliferation of fungal hyphae in the nodil tissues $(n)$. D) Longitudinal section of a stem from noninoculated control plants $(300 x)$.

parasitized by the nematode. The fungus did not seem to colonize mature gall tissue in preference to normal root tissue. These results differ to some extent from those reported by other workers $(7,8,15,16)$, in other crop plant.s. They have clearly demonstrated that there is a close relationship between the fungus and the root-knot nematode in roots of host 
plants parasitized by both agents. However, results reported herein agree in part because a maximum predisposition to Fusarium wilt, 4 weeks after the plants were exposed to the nematodes, was evident, since all the plants died because of the presence of the nematode. On the basis of this contention, it may be concluded that a positive interaction exists although the tissues were not simultaneously invaded.

The lesion nematode was located, either outstretched or coiled in the cells, within the cortex. It seemed to invade only the cortical tissues and not the vascular elements. Root sections showed severe necrosis in the tissues invaded. These observations showed that necrosis increases with increasing time interval after inoculation. Successive sections in root tissues invaded showed that nematodes as well as eggs deposited and infective juveniles were found in the lumen of the necrotic cells. According to Radawald et al, cited by Acosta (1), the high degree of necrosis of infected tissue is associated with a low initial resistance of the host caused by the parasitism of the nematode. It was also observed that in the cells affected, their walls became increasingly thicker. This is presumably due to an accumulation of phenolic compounds and to an increase of the oxidation of phenols with time after infection (1).

The $F$. oxysporum and $P$. coffeae association also revealed the presence of fungus hyphae and the nematode invading the same tissue. However, this association had no considerable effect on the incidence and/or severity of wilt caused by Fusarium at either combination $(\mathrm{P}+\mathrm{F}-\mathrm{S}$ and $\mathrm{P}+\mathrm{F}-4$ ). The slight increase in wilt symptoms induced by Pratylenchus in combination with the fungus is considered to be the result of the presence of avenues of entry produced by the nematode as it invaded the plant tissues (10).

\section{RESUMEN}

Se hizo un estudio en invernadero para determinar los efectos histopatológicos de la posible interacción entre los nematodos Meloidogyne incognita y Pratylenchus coffeae y el hongo $F$. oxysporum $f$. sp. dioscoreae en el ñame (Dioscorea rotundata) cv Habanero. Las inoculaciones se hicieron separadamente y en combinación del hongo y los nematodos. El estudio de secciones longitudinales y transversales de los tejidos radicales demostró que a los 14, 42 y 72 dias de la inoculación el hongo colonizó indiscriminadamente, intracelular e intercelularmente. En el tallo colonizó los tejidos vasculares, en los que se observó una gran proliferación de hifas, especialmente en los nudos. Tanto el nematodo nodulador como el hongo, aparentemente colonizaron secciones diferentes en los tejidos. Sin embargo, se encontró que las hifas eran más abundantes y vigorosas en secciones de tejido modificado por $M$. incognita. Estas observaciones sugieren una interacción positiva entre $F$. oxysporum $\mathrm{f}$. $\mathrm{sp}$. dioscoreae y $M$. incognita en ñame. En ocasiones se observó el nematodo lesionador y 
el hongo invadiendo simultáneamente los mismos tejidos. Sin embargo, esta asociación, aparentemente no tuvo efecto apreciable en la severidad o la incidencia de la marchitez causada por Fusarium.

\section{LITERATURE CITED}

1. Acosta, N., 1977. Host-parasite relationships of lesion nematodes, Pratylenchus Filipjev spp., and soybean Glycine max (L). Merr, Ph.D. thesis, Dep. Plant Pathol. Univ. Illinois, Urbana-Champaign.

2. —- and A. Ayala, 1975. Pathngenicity of Pratylenchus coffeae, Scutellonema bradys, Meloidogyne incognita and Rotylenchulus reniformis on Dioscorea rotundaia. J. Nematol. 7: 1-6.

3. Ayala, A., 1969. Nematode problems in Puerto Rican agriculture. In: Proceedings of the Symposium on Tropical Nematology. Ramos, J. et al. (Eds), Univ. P.R. Agric. Exp. Stn. 135-45.

4. Brathwaite, C. W. D. and E. J. Duncan, 1974. Development and histopathology of Rotylenchulus reniformis in sweet potato roots, Trop. Agric. 51:347-441.

5. Christie, J. R., 1936. The Development of Root-Knot Nematode Galls, Phytopathology 26:1-22.

6. Dimond, A. E., 1955. Pathogenesis in the wilt diseases. Ann. Rev. Plant Physiol. 6:32950.

7. Fattah, F. and J. M. Webster, 1983. Ultrastructural Changes Caused by Fusarium oxysporum $\mathrm{f}$. sp. lycopersici in Meloidogyne javanica Induced Giant Cells in Fusarium Resistant and Susceptible Tomato Cultivars. d. Nematol. 15:128-35.

8. Finley, A. M., 1981. Histopathology of Meloidogyne chitwoodi (Golden et al.) on Russet Burbank Potato, J. Nematol. 13:486-91.

9. Hussey, R. S. and K. R. A. Barker, 1973. A comparison of methods of collecting inocula of Meloidogyne spp., including a new technique, Plant Dis. Rep. 57:1025-028.

10. Inagaki, H. and N. T. Powell, 1969. Influence of root-lesion nematode on black shank symptom development in fue-cured tobacco, Phytopathology 59:1350-355.

11. Jenkins, W. R. and C. W. Bird, 1962. Nematodes associated with wild yam, Dioscorea sp. with special reference to the pathogenicity of Meloidogyne incognita. Plant. Dis. Rep. 46:858-60.

12. Johansen, D. A., 1940. Plant Microtechnique. McGraw Hill Book Company, Inc. N.Y.

13. López, J. and P. L. Meléndez, 1971. Wilt and candelilla diseases of edible yams (Dioscorea spp.) in Puerto Rico Annual Progress Report of Research Projects. Agric. Exp. Stn Univ. P.R.

14. Meléndez, P.L., 1965. Histological and physiological influences of root-knot nematode infections on the Fusarium wilt fungus in flue-cured tobacco. M.S. Thesis, Dep. Plant Pathol. N. C. State Univ., Raleigh, N. C.

15. - and N. T. Powell, 1967. Histological aspects of the Fusarium wilt root-knot complex in flue-cured tobacco, Phytopathology 57:286-93.

16. Powell, N. T., 1971. Interactions of plant parasitic nematodes with other diseasecausing agents. In: B. M. Zuckerman, W. F. Mai and R. A. Rohde, Eds, Plant parasitic nematodes. 11:119-36. Academic Press, N.Y. and London.

17. - - N. T. and C. J. Nuslaum, 1960. The black shank-root-knot complex in flue-cured tobacco, Phytophathology 50:899-906.

18. - P. L. Meléndez, and C. K. Batten, 1971. Disease complexes in tobacco involving Meloidngyne incognita and certain soil-borne fungi, Phytopathology 61:1332-337.

19. Wellman, F. L., 1972. Tropical American Plant Diseases. (Neotropical Phytophatology Problems) The Scarecrow Press, Inc., Metuchen, N. J. 